\title{
Certain Allegiances, Uncertain Identities \\ The Fraught Struggles of Dalits in Britain ${ }^{1}$
}

\section{MEENA DHANDA}

Superiority? Inferiority?

Why not the quite simple attempt to touch the other, to feel the other, to explain the other to myself? ${ }^{2}$

Power itself must be abolished - and not solely in the refusal to be dominated, which is at the heart of all traditional struggles [---] but also, just as violently, in the refusal to dominate. ${ }^{3}$

Research brought me to Britain twenty-five years ago and I stayed to make a living as an academic in a University. The complex example of the identity of a 'dalit' was at the centre of my philosophical investigations to explicate the concept of personal identity. After a gap of few years devoted mainly to teaching, I returned to researching the situation of Punjabi dalits. In the many conversations I've had with dalits in the Midlands, in the stories I have heard from them, in the ordinary and celebratory events I have participated in during the last five years, I have tried to understand the experience of caste prejudice ${ }^{4}$ and identify the specific forms of dalit standpoints against casteism. Am I well-placed to capture these forms?

I am mindful of the limitations of my position as a woman and an academic with an ambiguous caste/surname. As one might expect, many of my interlocutors assume what my caste would be - there are Dhandas who are Chamars. In most settings, I get introduced as 'she's ours' and I think I deserve this introduction, because in a sense - not necessarily shared by some - I am one of the dalits. With the inquisitive and more persistent enquirers, I share my inclusive meaning of the term dalit, which is not a synonym for S.C (the Scheduled Castes of the Indian Constitution) but a political term of self-reference with the potential to include all the 'oppressed'. If I am such a dalit, it is by virtue of my gender and colour. This is what I say to be counted as a researcher who is 'one of ours'. When working with a team, I have thus far relied on dalit research assistants. ${ }^{5}$

\footnotetext{
${ }^{1}$ An earlier version of this essay was presented at a workshop: 'The Internationalisation of Dalit and Adivasi Activism', 25-26 June 2012, Senate House, University of London. I am grateful to Professor David Mosse for the invitation and to the participants, especially the discussant Nicholas Jaoul, for comments. Primary research for this essay was conducted as a part of my transnational project - Caste Aside: Dalit Punjabi Identity and Experience - funded by a Leverhulme Research Fellowship from September 2010 to July 2012, for which I am very grateful to the Leverhulme Trust.

${ }^{2}$ Frantz Fanon, Black Skin, White Masks, (Peau noire, masques blancs, 1952; tr. 1967; London: Pluto, 2008 ): 181.

${ }^{3}$ Jean Baudrillard, The Agony of Power tr. Ames Hodges, intro. Sylvère Lotringer (Intervention 6; Los Angeles: Semiotext(e), 2010) : 47

${ }^{4}$ A government sponsored study published by the National Institute of Economic and Social Research (Metcalf and Rolfe 2010: 63) notes: 'The study has found evidence that caste discrimination and harassment is likely to occur in Britain. Evidence has been found in respect of work and the provision of services.'

${ }^{5}$ The affinity between the researcher and the subjects of research is perhaps more in question when the difference is not 'visible'. When the difference is visible, respondents might attune their responses for the benefit of the 'outsider'; in such cases, to get relatively unembellished responses, the solution of teams of researchers might be feasible. See Eleanor Nesbitt "Research Report: Studying the Religious Socialization of Sikh and 'Mixed-Faith' Youth in Britain: Contexts and Issues," Journal of Religion in Europe 2 (2009): 50. Nonetheless, no matter how close a correspondence exists between the researcher and the researched, in the interview situation, the researcher embodies symbolic capital in being the one who asks the questions. Even the closely identified researcher exercises a power that is bound to elicit a 'performance' in the interchange. Therefore, it is important that the researcher herself is open to questioning by the respondents; genuine exchanges cannot be one-way.
} 
While the title of my essay signals some negativity with 'fraught struggles', I suggest that, paradoxically speaking, this is equally evidence of health, of a palpable, though, uncategorized vitality. Indeed, I do think that we can identify many different sources of counter-power to the routine undercurrents of continuing caste prejudice. There is dalit protest, though not united or directed by common goals. I will also suggest that in the interpersonal domain, where prejudice is most deeply felt, there is a lack of articulation, which needs remedying. In all of this to use the words of Brennan (2012):

My point is to insist on the situatedness of truth, on the involvement of the researcher in the object of research, and, above all, on the nature of the real as contradictory and conflictual. ${ }^{6}$

Then there is the undeclared 'other' from whom recognition is sought. Could it be that the 'fraught struggles' are so embroiled because the different layers of conflict within dalit communities stem from irreconcilable desires? I will suggest that an honest recognition of irreconcilability could be a source of strength and need not hold-back collective efforts for seeking redress and amelioration where feasible.

My illustrative examples are taken mainly from the West Midlands and within it often from Wolverhampton. In 2009, there were 238,500 people living in Wolverhampton. Of these, 172,900 (72\%) were White British; 8,800 (4\%) were White Other; 7,600 (3\%) were Mixed; 32,900 (14\%) were Asian; 12,300 (5\%) were Black; 2,300 (1\%) were Chinese, and 1,700 (1\%) were in the Other group. ${ }^{7}$ The Indian population is twice as concentrated in Wolverhampton compared to the region of West Midlands. The city has Christians, Hindus, Buddhists, Sikhs, Muslims, Jews and people with 'Religion not declared' or 'No religion' from different ethnic groups. In the declared religious following of the Asian population, which has steadily declined in Wolverhampton, according to the census of 2001 there were 803 Christians, 384 Buddhists, 8,973 Hindus, 0 Jews, 3,361 Muslims, 17,621 Sikhs, 63 people of 'Any Other Religion', 523 of 'No Religion', 2,138 of 'Religion Not Stated'.

The impact of the vigorous campaign among Ravidassias during the latest census period to declare themselves as 'Ravidassia' in the 'Any Other Religion' category has had a result. For the first time in the UK, 11045 people in England are counted as Ravidassias and a majority of these (6690) are in the West Midlands. ${ }^{9}$ Discussions amongst Ravidassias on Facebook groups has partly celebrated these results, but partly seen them as disappointing.

The question of religious identity is still uncertain, and it is only tenuously related to allegiance to the style of worship. As it is central in any negotiation of identity, the practical defines the direction of struggle here too. ${ }^{10}$ Using the words of my respondents I shall paint word-pictures of how things appear to me. Each portrait is flagged by a heading, which singles out one aspect of the many sources of friction. Together the portraits are presented as a gallery, by no means exhaustive in coverage, but hopefully with sufficient depth to encourage sustained enquiries by others who might want to join me in my endeavours.

\section{The Generation Gaps}

There are different aspects of the gap, which get manifested in varying ways. Parents generally tend to report that their children are not aware of caste differences. An ex-President of the Ambedkar Memorial Committee, Wolverhampton,

\footnotetext{
${ }^{6}$ Timothy Brennan, "Diaspora, Intellectuals, and the State," Occasion: Interdisciplinary Studies in the Humanities 3 (15 March 2012), http://occasion.stanford.edu/node/77 (accessed 20 October 2012).

${ }^{7}$ These are based on Mid-Year Estimates issued by HMSO in May 2011, published by Corporate Strategy and Improvement Unit, Wolverhampton City Council, 'Research and Information briefing', June 2011.

${ }^{8}$ I am grateful to Adrian Barlow, Information \& Research Officer, Corporate Strategy and Improvement Unit, Office of the Chief Executive, Wolverhampton City Council for providing all population data.

${ }^{9}$ The largest number of Ravidassias declared from any one place are from Wolverhampton (2186), followed by Birmingham (2024), Sandwell (1032), Bedford (946), Walsall (653), Ealing, (525) and then Coventry (436). See http://www.ons.gov.uk/ons/dcp171776_290510.pdf (accessed on 11 December 2012).

${ }^{10}$ See Meena Dhanda, "Negotiating Practical Identities," in Self-knowledge and Agency, ed. Manidipa Sen, for a general discussion of 'practical identity' and "Punjabi Dalit Youth: Social dynamics of transitions in identity," Contemporary South Asia 17.1 (2009) for previous work on Punjabi dalits.
} 
says: "If you look at the young people, they are not challenging the caste system." When I ask his views about those young people who marry out-of-caste, he says:

[It's] marriage of opportunity or convenience - not done to break caste or abolish the system. They are selfish, they are for themselves....not (trying) to get rid of stigma. ${ }^{11}$

When I interview a young woman at the sixtieth birthday party of a Buddhist member of the congregation, and ask about her experience, she reports 'segregation in the playground' due to caste and when asked what in her view is the reason for the continuation of caste prejudice in the UK she says: 'it is passed down from the older generation'.

The generation gap manifests itself in yet another way when an elder Valmiki gentleman claims that the younger generation born and brought up here do not care about caste, but his son reports that he has routinely faced caste prejudice: at work, at school, in personal life. The son relates a story of an encounter from his days as an employee at the Post Office. He took up employment straight after leaving school, against the wishes of his father who wanted him to study further, and rose to a manager's position. One day, he asked a female colleague, in his capacity as her manager, to move from the area she was working in, to another, and faced her annoyance as a result. He reports:

Then... she goes... Oh! I am a Jatt and I'm a high caste.....I say why do you say that? What are you on? I say what are you talking about...everybody is wearing uniform, I say we're all the same... I say you got no uniform at this moment...(laughs) and you're making a big scene, I say even if you did, you'd still be the same person, I don't care whether you're black or white or whether you're this caste or that, you're a colleague and you're a post-woman at work, everyone's the same, right. But she just couldn't take it!

He complained to his line manager who called her in along with one Mr Singh. The result of the meeting was not to his liking. My respondent continues:

They just said that they've got no knowledge of it and that they can't really investigate, so it just got squashed. But it left me hurt, but I just played the game, cause... I'm very strong. I've been taking it all my life anyway, not just black and white but with adult people, 'what religion are ya?', 'what caste are ya?'

I ask for clarification of Mr Singh's role in the meeting and he elaborates further:

Me: But I don't understand...could he...did he say that she was right to not listen to you?

He: No he says that she...not...not to listen to me...but that she was right that 'we are the higher caste'...so that's why it got squashed, that's why she was in order... that's what I just mentioned... it was brushed under the table...just to get her out the...so she wasn't going under no kind of investigation...because they've got no knowledge of how to attack it. $^{12}$

While his father was of the view that the younger generation is not concerned about caste - assuming that they do not care and do not want to know, it was surprising to hear him say that he'd faced discrimination all the time. He was evidently left with a feeling of frustration that his employers did not properly understand the situation. He could not take the matter further, even though his employers could be seen as siding with caste prejudice, through their inability to deal with it in an informed way. The employers had followed the required routine of asking an expert and got an answer that let off the culprit. He had to let the matter go because of their ignorance.

A phrase he repeated at least four times - 'I shower and I am polite', was indicative of how he has personally addressed two deep-rooted prejudices about dalits, that 'they are unclean' and that they 'use foul language'. He did not present his motto as a universal response to prejudice, but as his singular response that in interpersonal relations helps him achieve smooth interaction.

He was also critical of his father's generation's prejudiced view of 'Jamaicans'. When I probed this thought of prejudices further and shared with him another recurrent feeling, the general anti-Muslim feeling, picked up among respondents elsewhere, he recalled that as a child he was told 'Do not trust a black or a Muslim'. In my interview with the father, when he commented on the 'self-interested' attitude of the Jats: 'they will do what suits them', with the

\footnotetext{
${ }^{11}$ Personal interview on 7 March 2012.

12 Personal interview on 17 June 2012.
} 
further comment: 'they are no less than Jamaicans', I had pointed out the anti-black prejudice in his statement. The son too had linked the two poles of prejudices Indians veer between: race and caste.

The difference between the younger and the older generation emerging from this case lies in the manner of acknowledgement of the existence of caste prejudice. The father has faced caste prejudice back in Punjab, denies ever being a victim of caste discrimination or prejudice in the UK, is of the view that the life of dalits in this country has improved in all areas of life, including caste-related conflicts, in the last two decades. Yet, he thinks about his caste all the time, believes that caste discrimination exists in the UK, and thinks that religious institutions should take a lead in combating it through their teaching, albeit, alongside legislation.

His son on the contrary, almost never thinks of his caste, despite reporting that he has been a victim of caste discrimination and prejudice at work, in provision of services, at school and in personal relations. Even so, he considers racist prejudice as a bigger problem than caste prejudice, but unlike his father believes that caste conflicts within the community are the same as 20 years ago, not lessened. He thinks that the law should be used to combat caste discrimination or prejudice, 'just like in racism'.

I think that the key to understanding this difference in acknowledgment lies in noting that the younger generation is confident in facing prejudice. Prejudice can be named because it is a facet of the others' bad behaviour. It is not about them. The younger generation are less affected by ascriptions of caste inferiority because they identify less with caste hierarchy. Some among the younger generation are even keen to embrace caste difference and assert a separate identity, freed from the yoke of inferiority. For the older generation, the historical consciousness of past indignities makes the connection between ascription of caste identity and inferiority still a disturbing issue. The denial of personal victimhood, while asserting existence of prejudice elsewhere seems an easier route to self-respect.

The big difference also lies in the emotions underlying the two attitudes of acknowledgement and denial of the experience of caste prejudice. The young laugh at ascriptions of inferiority, while retaining a detached annoyance at continuing caste prejudice. In the case of the older generation, however, indignation turns to expletives when their memory is jolted; they are relieved to be away from the harsher realities of penury associated with the so-called 'lowcastes' back in Punjab, but are touchy about reminders of that reality. It is a delicate balance, which is threatened by resurging inter-group conflicts.

The following section takes up one such sticky situation of separation between the Sikhs and Ravidassias in the UK.

\section{Unsettled Separation}

A lot has been eloquently written about the emerging consciousness of a separate identity among Ravidassias in Punjab mainly led by the followers of Dera Sachkhand Ballan. ${ }^{13}$ The influence of this Dera's followers in Wolverhampton is yet uncertain. As is well known, the killing of Sant Ramanand in 2009 in Austria is taken as the straw that broke the camel's back: Ravidassias will no longer accept the hegemony of Jat Sikhs in their own place of worship. Gagandeep Nar, a young activist in the Midlands describes the killing as a 'Shaheedi' (sacrifice), which was an attack on the intellect of the Ravidassias. "Kill the brain", so that the movement cannot go forward: that is what they wanted', he says with mixture of anger and hurt.

Older members of the community also suggest a progression to separation: 'When a community becomes stronger, they separate'. In a similar vein, the President of the Guru Ravidass Sabha, Wolverhampton, says:

We have our own Nishan - 'Har'. Apart from Sri Guru Granth Sahib, everything is separate.' (He takes out of his pocket a white kerchief with the 'Har' insignia printed in blue on it). ${ }^{14}$

A young married woman is very vocal in criticising what she sees as the appropriation of the thought of Guru Ravidass in the Guru Granth Sahib. She complains that up until 2009 'they never used to even celebrate anything'. She says that people are 'too scared' of 'the other... higher-caste Sikhs'. When I ask why they are scared, she elaborates because 'everybody mingles with each other, there's people married into each', for example, her cousin, a Chamar girl, is

\footnotetext{
${ }^{13}$ See Ronki Ram, "Beyond Conversion and Sanskritisation: Articulating an Alternative Dalit Agenda in East Punjab," Modern South Asian Studies 46.3 (May 2012): 639--702. doi:10.1017/S0026749X11000254.

${ }^{14}$ Personal interview on 14 October 2011.
} 
married to a Jat boy. The fear presumably is that if a separation in religious worship is insisted upon, relatives might get annoyed. When I ask how common is mixing of this sort, she says:

just recently, it's accepted but it has to be on their level, it has to be on their terms; they don't get married in our temples....whether they're Tarkhan or Jat, they just don't... "we're not coming to the temple to get married" [they'd say]...It's happened on a number of occasions that we've been to their weddings, but they won't come. ${ }^{15}$

Her younger teenage sister recounts another example of the temple refusing to marry an inter-caste couple because the surname of the boy from the Chamar community was 'Kumar' and 'they refused it...it had to be Singh'. This information coheres with what I have heard from two other respondents. The President of the Guru Ravidass Dharmic Sabha, Dudley Road, Wolverhampton, reported that people with the surnames 'Das' or 'Ram' presumably non-Sikh, would not be able to marry in a London Gurudwara.

The move for separation, it appears, is not a unilateral one pushed by supporters, but a two-way process with an escalating dynamic. My conjecture is that in response to the threat of separation of Ravidassias, an internal realignment of practices among upper-caste Sikhs along egalitarian lines is on the agenda, supported by left intellectuals as well as religious orthodoxy. However, as the fault-lines are first and foremost drawn along religious lines, it is religious orthodoxy which has a bigger role to play. For example, the Nishkam Centre, the self-styled defenders of Sikh values in the UK, instructed that consumption of meat and alcohol at the Dudley Road Community Centre be stopped, because on special occasions the Guru Granth Sahib is taken to the Community Centre from across the Temple, where daily worship takes place.

Whatever be the details of the quarrel, the general point is that eradication of caste hierarchy among 'highcaste' Sikhs is premised upon a puritanical religious attitude or 'fundamentalism'. Male Ravidassias, typically with shorn hair, and accustomed to alcohol and meat consumption, like the majority of Punjabi male population, are not inclined to adopt Sikh-baptism as a means of protecting themselves from slurs of caste-inferiority. It is possible that one of the reasons offered for the refusal of Gurdwaras to conduct marriages of people with the surnames Das, Ram or Kumar, is that all 'true' Sikhs must only have Singh and Kaur as their surnames. It seems that Sikhs are trying to set their own house in order, while also attempting to welcome back the estranged, neglected, maligned and ill-treated 'lesser' relative - the Ravidassia. But the egalitarian move to embrace Ravidassias that 'high-caste' Sikhs make from within the cultural sphere defined by Sikhism, in fact, pushes them further away towards separation. Sikh fundamentalism is now felt less as an embrace, and more as a stranglehold.

One respondent in Wolverhampton said: 'We used to say - "Sat Sri Akal"; now we have our own greeting "Jai Gurudev". The issue that divides the Ravidassias is the one of the Granth. I was lent a copy of the Bani of Guru Ravidass (published with an English translation from Kanshi, UP, India, in February 2012). I have heard that the marriage ritual of lavan-phere, performed typically by walking in tandem around a bedi (holy fire) or the Guru Granth Sahib, accompanied by singing from the Granth, has started being performed with the Bani of Guru Ravidass. The first of such weddings according to one of my respondents took place about two years ago. The most recent innovation in the ritual is the carrying of a staff with the 'Har' emblem instead of the traditional Sikh sword by the bridegroom ${ }^{16}$.

When I asked an elderly Valmiki gentleman to comment on Ravidassia's move to separate from Sikhs, he said that he clearly supports the separation. When I pointed at division among Ravidassias on whether or not to house the Guru Granth Sahib in their own Gurdwaras, he said that it was Jats who instigate the fights, by asking Ravidassias to return to the fold. It was too late, according to him, to now expect a return, when they have for so long failed to practise the equality that they preached. He also noted, in a different context, the strength in numbers of the Valmikis, Mazhbi Sikhs and Ravidassias put together in Punjab, and concluded that if they were to be united, they could 'thrash and throw out' the Jats, many of whom were already selling land and moving out.

In an uncommon way, the sentiment of distinctness from upper-caste Sikhs is also expressed by the Valmikis. One respondent shares a photocopied page from an encyclopaedia with these words:

\footnotetext{
${ }^{15}$ Personal interview on 9 June 2012.

${ }^{16}$ From an interview with a young Ravidassia on 4 May 2012.
} 
We believe we are adivasi...our colour is also dark.....it is here - you will read it...Aryans introduced the Rig-Veda as it says here (pointing to photo-copied extract). ${ }^{17}$

\section{Leadership Wrangles}

Conflict in the Dudley Road 'Guru Ghar' has been ongoing for a long time due to different issues. One of my young respondents, whom I have known for over five years, explains that there are bitter fights about Chaddawa (money collected) or which Ragis (singers) to invite, but the underlying issue is who has control of the institution.

A split has also occurred among the Buddhists in Wolverhampton with two different establishments vying for the same congregation. I do not have the full sketch of the underlying story but the divide seems to have occurred at the appointment of a successor to the officiating monk. Subsequently there is a difference in emphasis in the activities undertaken by the two establishments, otherwise located close to each other. Different members of the same family diverge in their preferences for engaging in religious activities at these centres.

At Dudley Road, the strain came with the visit of 'Chotte Maharaj' Sant Ramanand from Dera Sachkhand Ballan. He got a lot of Chaddava (monetary offerings) and he allegedly took them back with him to Punjab. According to my respondent, this is one issue that caused a lot of upset. He was of the view that the Sant was right to take the offerings with him, because if the congregation wanted to give the offerings to the Gurudwara instead, they would have. He added: "They gave to him, so it's right that he took it back; I fear that the money might be misused here...Money goes missing...figures don't balance." One cannot establish the provenance of these allegations but they are sufficient to show the existence of distrust in the managing committee regarding financial matters, reiterated by other respondents, which then becomes a source of split loyalties.

An elder Ravidassia respondent closely involved with the working of the committee, having participated in the writing of the constitution in 1993, explained the complex process of election of the 50 members from seven areas (wards) with each sending delegates in proportion to the area population. At the time of my interview with him (March 2012) the process of re-election was going-on and he predicted that the outgoing President may not give charge as he preferred to switch to one-person, one-vote system. There was also some difference of opinion with the UK Ravidassia Sabha. I was told that $£ 80,000$ had been spent on lawyer's fees for the defence of one of the members of the local committee: such a cost of litigation was seen as an unfair drain on funds. This understandably appears as 'misuse' of funds by lay members of the congregation like my young respondent who preferred the collection on the occasion of the visit of Sant Ramanand to be taken to India rather than be left in Wolverhampton.

There are no principled struggles here fought over the issue of 'rights' or 'representation' or 'democracy' but very human wrangles over money and personal power. However, this does not mean that the congregation favours the removal of the Guru Granth Sahib and its replacement with Guru Ravidass's Bani, advocated by the Ballan Dera. The issue of separation is tied to leadership control, but not wholly determined by it.

There are many who are against the move to install the Bani. One such is the Ravidassia taxi driver who has ferried me dozens of times and regularly shares his views about developments in the community. He often describes members of the committee as: 'a bunch of jokers' and blames the infighting for 'why our community does not go forward'. He thinks it 'stupid' to want to remove the Guru Granth Sahib, which has 'so much more' to offer than the Bani alone could.

By way of international links, there is support for the project of building a mandir at the Valmiki Teerath in Amritsar, the President of the Bhagwan Valmiki Sabha, Wolverhampton, Mr Fakir Chand, confirms. He also reports that they had funded a Chair - Maharaj Valmiki Research Chair, held by Dr Inder Mohan Singh at Punjabi University, Patiala.

The Ambedkar Memorial Committee has supported a project of building a Buddha Vihar just outside Ludhiana. One Ravidassia respondent reports that UK dalits make donations to hospitals, schools, eye camps, and a water project in Punjab, usually linked to religious establishments. My respondents have not reported supporting any non-governmental organisation in Punjab.

\footnotetext{
${ }^{17}$ Personal interview on 18 March 2012 (morning).
} 
My suggestion at the end of a speech in Wolverhampton that scholarships should be instituted for dalit studies in the UK, especially to support dalit students from Punjab to come and pursue post-graduate research with us received warm support from the community, including words of support from the Local Councillor Mr Mattu at a gathering of 300 people to celebrate the $121^{\text {st }}$ birth anniversary of Dr Ambedkar this year in Wolverhampton.

\section{Diverse Responses to Prejudice}

A Valmiki owner of a local transport business in Wolverhampton relates a story of complex negotiations of caste privilege and revenge stemming from affinity as well as hierarchy. All the van drivers in his company were Jats. His company was engaged in contract work for a larger firm whose foreman was also a Jat. The Jat foreman allegedly looked for loopholes and grounded all the contracted vans. The rest of the story is narrated thus:

The main owner of the company was also from S.C. biradari. I approached him directly and told him that the reason [for grounding the vans] is our being Valmiki. Then six months later we got back the contract. I told him you are also S.C. and so am I....he has done this deliberately...so he sacked the foreman. ${ }^{18}$

He goes on to say:

I have never felt I am low-caste. Jo ha(n) sahi ha(n); asi raje han! (Translated: We are right, just as we are; we are kings!)

He has a relatively affluent background from Punjab from where he migrated in 1998; his father owned 30 acres of land near Kapurthala and had Jat servants. Of his current exchange with his Jat employees he says:

I eat food - they take away the dishes... They do feel bad... Rubb de chakur. (Translated: God's wheel [of fortune])'

His experience of mixing with Jats in Britain is riddled with ambiguity. He is friends with Jats, they eat together, but he says:

They do not know who we are...they never ask us and we never asked them (about caste). If asked we will tell.

Mathe te likh ke nahi chalde (Translated: we do not proceed by writing it on our foreheads)

In response to a specific question about the acceptability of music using caste names, this Valmiki respondent says with some relish:

Jatt murakh log hun...Brahman kyon nahi kehande: "putt Brahmana de”...Akal ghat hai

(Translated: Jats are foolish people...Why don't the Brahmans say: "Sons of Brahmans”...Intelligence is lacking')

He gives as evidence of their 'foolishness' their unreflective acceptance and dancing to an ironical song from 2002, sung by a Valmiki, Ranjit Mani:

Chite chadre, zamina ghehne

Putt sardaran de

(Translated: Dressed in white, land mortgaged/ Sons of landowners)

There is clearly a sense of achievement in my Valimiki respondent's words, having acquired wealth and a standard of living sometimes outstripping Jat competitors.

He has done well for himself; he is self-employed and drives a Mercedes. He was of the view that he would educate his children in private schools and if his son were driving a Ferrari, no one would dare to ask about his caste. Financial power was the solution to combat caste prejudice in his view and his attire of designer clothes accessorized with solid gold chains and bracelets was symbolic of the status he expected to occupy in the Punjabi community.

\footnotetext{
${ }^{18}$ Personal interview on 18 March 2012 (late afternoon). Misgivings about the behaviour of Jats are noted by other researchers too. Thus one of Ghuman's respondent says: 'It is not the Brahmins who suppressed us but the Jat community' See Paul Ghuman British Untouchables: A Study of Dalit Identity and Education (Farnham: Ashgate, 2011): 58.
} 
However, a vast majority of my respondents did not consider accumulation of wealth as the most desirable means to combat caste prejudice. Regardless of whether or not they were successful in accumulating wealth, most respondents trust education to take them forward. Thus an elderly Valmiki man points out that Maharaj Valmiki in the only guru who has a quill in his hand; he was Vidyavan (a scholar-sage). He adds with indignation in his voice:

Knowledge (Vidya) has been snatched from us. That is why we were handed the broom. We now want that the broom should be thrown away and once again in our community, to bring back the quill. A quill is needed. With the quill will come the end of all superstitions, disease, afflictions, economic depravations.....the quill will bring this (Translated from Punjabi).

This elderly gentleman also mentions his association with the communists towards the end of my interview with him his home village is close to late Harkishan Singh Surjeet's, the stalwart CPM leader. He recounts with bitterness a jibe made by a comrade while a party meeting was on:

Dekhin, bhukhi biradari taun hai, kapde sohne paye aa!

(Translation: Look! Comes from a starving community, wears fine clothes!)

On this occasion he asked the party president to: 'note this point'. His association with the Punjabi Left in this country continues in a low-key and he notes that the party is 'down' these days. He is a Labour voter in the UK and an Indian National Congress supporter in Punjab.

The older generation of migrants recount similar stories of stigmatization from their youth but none of severe atrocities. Indeed, they sometimes assert their superior sense of dress, culture and comportment compared to Jats. Thus, an engineer from the Ravidassia community tells me of an encounter with a neighbour, while in overseas employment in the Middle East. This neighbour, a Saraswat Brahman doctor, whose father was a retired university lecturer, asked him about his caste on the occasion of a special dinner after Shivratri. My respondent reports thus:

They ate with their hands, I was disgusted! I was eating with forks....I didn't answer their question about caste.

Didn't know how they will behave if they knew. ${ }^{19}$

The desire to remain incognito with respect to caste status is a factor which divides the community. Some people take a principled position with respect to declaration of caste status. Thus an elderly Ravidassia man from the West Midlands says: 'when my guru could call himself Ravidass Chamar why should I hide my caste? I tell everyone who I am.'

Other people do not think it necessary to divulge their caste. There is the fear of stigmatization, of humiliation and even of rejection. Yet others, a minority among my respondents, are proud in the personal sphere to maintain separate caste based allegiances, but would not like 'caste' to be a part of legislation: 'Highlighting it will make it worse'. Quite the opposite, a mature post-graduate woman, having faced caste prejudice, supports legislation, 'because it's very real'. In her personal life, however, she refrains from declaring her caste:

I have a friend who is from a Sanyaara caste and she...I don't think she knows I'm a Chamar, and I've never....I never tell people because I don't think it's got anything to do with who I am as person, that I shouldn't be identified as...I am "me", I am a human being and I have a right to be equal and so I don't give them anything to give me an inequality and it can; she sometimes says "o choorhi, chamari jahi" and you know, I think "...do you know who I am? Do you know where I come from?” But then I don't say anything and sometimes I think well why don't you say something? And you know, because it does hurt, it hurts when somebody uses the term to be really negative about somebody and you know you think, well, why would you do that? And she is from my generation. ${ }^{20}$

The hurt is unmistakable and the story a reminder of a similar pain, when Fanon was pointed out: "Look, a Negro!" and he lamented: "All I wanted was to be a man among other men"21

\footnotetext{
${ }^{19}$ Personal interview on 4 March 2012.

${ }^{20}$ Personal interview on 13 November 2011. Writing about caste-based divisions in Leiceste, Sato (2012: 18) very wisely concludes: 'We ought to listen to their demands to 'oppose all caste-based discrimination', and their bitter experiences and 'voices'. These are not made lightly.'

${ }^{21}$ Fanon, Black Skin, White Masks, 84-85.
} 


\section{Scope for Activism}

The elderly Valmiki, I have cited above, has hopes for a united front of Valmikis, Ravidassias and Buddhists: a sure way of giving a death blow to the supremacy of the Jats, he thinks. The young Ravidassia, on the other hand, is very sceptical that any such unity is even remotely possible. He says: "There are too many factions within the community to even attempt a united front." Gagandeep Nar is an optimistic activist. I met at the $121^{\text {st }}$ birthday celebrations of Dr Ambedkar this year in April, where both of us addressed a public meeting in Wolverhampton. He is for a distinct identity of Ravidassias. He manages a very active Facebook discussion group and interacts on a regular basis with other groups discussing the issue of Ravidassia identity. In a recent entry (19 October 2012 @ 9:03am) he wrote:

Why people ask these questions: -? Who u r? What is ur surname? What temple u go to?....I have been asked these questions so many times. I use to say I am Chamar, I go to Shri Guru Ravidass temple....Or I had to tell where I from; blah, blah, blah: now I just got one answer that "I am Ravidassia" and people got their answer. When u openly say what we are, society respect $\mathrm{u}$ more because we not hiding anything and other got nothing to ask. Identity is important key for equality and respect. Jai Gurdev. [unedited].

Another regular contributor, Sunny Kainth, says:

We are lucky to be living here in the U.K., but the sad fact is that here in this country we still get questioned about caste...all because it gives the person asking a cheap high for that sad little moment....even if there [sic] living standard is lower then [sic] ours they still try to belittle us. To be proud is very important it will make life so easy for our young in time to come.

This stance is not unchallenged and one male commentator asks:

Don't you think you are giving too much attention to the Sikhs....I was born here and lived all my life here and I've not had any problems with discrimination. Why must you always appear as the victims. [unedited].

This exchange illustrates the complex workings of the dyadic nature of humiliation encapsulated in Ashis Nandy's view that 'humiliation is a form of human relations that can never be a one-way exchange.' (2009: 42). But Nandy overlooks the intelligence that allows a human being to recognize the 'attempt to belittle' without succumbing to it. Just as the commentator above misses the point made by Kainth, Nandy too applies his two-way exchange model to blame the one who is complaining about being humiliated. 'Aren't you giving too much attention etc.' Both underestimate the capacity of the claimant to shield herself from the attempt to humiliate while fully recognizing it. What Nandy fails to grant is that one could assume the posture of being angry at being made a target of humiliating treatment, without actually losing oneself in that anger. If one can play at being a sycophant in a manipulative way, to undercut the power of the upper-caste, as Nandy allows, why cannot one also play at 'being humiliated'? Especially for those taking leadership, as Gagandeep and Sunny, in showing a way out to those who do feel humiliated by caste prejudice, this tactic of pointing out the attempt to humiliate would be pertinent.

An example of this leadership role suggesting a solution to the quandary faced by Ravidassias is in the following comment by Sunny:

we are different altogether so this leads me to the question why cant we have both amrit bani and ggs ji in our guru ravidass ji temples why not? ${ }^{22}$ [unedited]

This dual holy book solution is reminiscent of the move made many years ago by Majhbi Sikhs and Hindu Valmikis described by Davinder Prasad, the General Secretary of CasteWatch UK:

Majhbi Sikhs joined Hindu Valmikis and founded the first Valmiki temple in UK and Europe and agreed to have two holy books in one temple where both Majhbi and Hindu Valmiki communities could practice their religious beliefs without caste coming in the way. When I was general secretary of Maharishi Valmiki Sabha Coventry, I saw this as

\footnotetext{
${ }^{22}$ Sunny Kainth (5 Oct 2012 @ 9:26am) (Facebook group UKRavidassia, a closed group with 69 members- 9 women and the rest men and other groups).
} 
a big step forward where Valmikis recognized that if they want to live their lives with pride and dignity, it is possible in UK. On Sangrand recitation of Guru Granth Sabha followed by reading of Ramayan (vak laina) was practiced. ${ }^{23}$

Valmikis in Coventry, described as a group with 'a unique heritage of pride and pain' (Nesbitt 1990: 271) discontinued their admirably accommodating practice of worshiping two holy books, five years ago, due to pressure from orthodox Sikhs, similar to the one being faced by Ravidassias today to abide by mainstream Sikh Maryada of treating the Guru Granth Sahib ji as the sole authority worthy of worship. ${ }^{24}$

On the basis of the stories I have recounted above, if one were to think of how one might go about addressing the causes for the continuation of caste discrimination and prejudice, it seems obvious that activism cannot be restricted to merely lobbying for a change in legislation. However, to provide a quantitative evidential basis, besides conducting in-depth interviews, I also solicited responses through completed questionnaires, and found the following response by a mid-20s man to be the most comprehensive list of causes for the continuation of caste discrimination or prejudice in the UK: "peoples stupidity, immaturity, warped mentality, their arrogance, wrong teaching, double-standards".

In terms of numbers, of the 25 completed questionnaires in Wolverhampton, 19 respondents support the use of legislation in the U.K. to check caste discrimination or prejudice, 5 do not want it to be used and 1 abstained from answering the question. An even larger number than those who support legislation, 23 out of 25, agree that in general caste discrimination does exist in the U.K. (1 denied, and 1 abstained).

There are deep matters here, about changing relationships in an integral way. Education may have a role, but there would also have to be a role for making the emotional sphere of life more permeable to allow genuine symbolic exchanges between people. ${ }^{25}$ 'Only by working and thinking together can we work out mutually respectful and cooperative habits of interaction' ${ }^{26}$ Art, music, film, literature: all are crucial in this regard.

In this essay, I considered the responses of Ravidassias, Buddhists and Valmikis to the experience of caste prejudice to illustrate the claim that their allegiance to their places of worship is congealed, while their identities as dalits remain in a flux. In other words their loyalties are certain, even as their identities remain uncertain. There is an ambiguity of self-identification as dalits and an inner tension often expressed in decisions about whether or not to support the exit options taken by the second and third generation of migrants in choosing to marry out of caste. ${ }^{27}$ The factors underlying this dual movement are various. Of significance is the complex positioning of dalits apropos the so called 'upper-castes' in the socio-economic sphere in Britain, where some have acquired significant wealth and accompanying status. Considerable energies are spent in checking the spread of fissures caused by intra-organisational politics that regularly threaten the otherwise congealed allegiance of groups to their respective places of worship and congregation. Being the largest group with the fastest growing economic power, among all dalits, the Ravidassias are perhaps the most geared towards self-definition in the U.K., while the significantly smaller in number, Christians and Buddhists, focus on strengthening 'global connections'. ${ }^{28}$

Dalits have not yet fully reacted to mainstream Hindu denial of castism in Britain. Rather than blame 'uppercaste Hindus', they take Jat Sikhs as their common 'enemy', highlighting the fact that the upturning of everyday relations of domination are the key to understanding the position of the dalits in Britain. Criticisms of Brahmanvad, the supremacy of the Brahmin, may occur in public speech-making alongside worshipful references to Dr Ambedkar's sacrifices for dalits, especially his instituting of reservations, which helped move forward their brothers and sisters in India, but the driving force for reform in the UK, is not an intellectually inspired criticism of casteism so much as a

\footnotetext{
${ }^{23}$ Several interviews from 2008 onwards; this version in written confirmation of a phone interview, by email dated 26 August 2012.

${ }^{24}$ Ghuman, British Untouchables: A Study of Dalit Identity and Education, 29.

${ }^{25}$ I have written about inter-caste marriages in Punjab in Meena Dhanda, "Runaway Marriages: A Silent Revolution," Economic and Political Weekly (27 October 2012): 100-108.

${ }^{26}$ Elizabeth Anderson, The Imperative of Integration (Princeton NJ: Princeton UP, 2010): 187.

${ }^{27}$ For a discussion of exit options and the development of the idea of symbolic exchanges in inter-personal relations see Meena

Dhanda, Caste Aside: A Philosophical Study of Identity and Resistance of Punjabi Dalits (New Delhi: Routledge, forthcoming).

${ }^{28}$ See Eva-Maria Hardtmann, The Dalit Movement in India: Local Practices, Global Connections (New Delhi: Oxford UP, 2009). This work includes ethnography of Buddhists in Wolverhampton, but not of Ravidassias. For an early and highly regarded work that makes the global-local connection amongst Ravidassias in Wolverhampton see Mark Juergensmeyer, Religion as Social Vision: the Movement against Untouchability in $20^{\text {th }}$ Century Punjab, (Berkeley: U of California P, 1982).
} 
repugnance of the way in which Jat Sikhs are seen to assert their superiority. The Equality Act 2010 could be used to keep this assumed supremacy in check, and such a measure is likely to be supported by a vast majority of dalits in Britain, though not favoured by all.

Beyond legislation, though, at a personal level we must learn to refuse to dominate, even as collectively we register our refusal to be dominated. With Fanon again: 'At the conclusion of this study, I want the world to recognize, with me, the open door of every consciousness' ${ }^{29}$

\section{WORKS CITED}

Anderson, Elizabeth. The Imperative of Integration (Princeton NJ: Princeton UP, 2010).

Baudrillard, Jean. The Agony of Power, tr. Ames Hodges, intro. Sylvère Lotringer (Intervention 6; Los Angeles: Semiotext(e), 2010).

Brennan, Timothy. "Diaspora, Intellectuals, and the State," Occasion: Interdisciplinary Studies in the Humanities 3 (15 March 2012), http://occasion.stanford.edu/node/77 (accessed 20 October 2012).

Dhanda, Meena. (2009) "Punjabi dalit youth: Social dynamics of transitions in identity," Contemporary South Asia 17.1 (March 2009): 47--63.

Dhanda, Meena. "Negotiating Practical identities," in Self-Knowledge and Agency, ed. Manidipa Sen (New Delhi: Decent Books, 2012): 277--302.

.... "Runaway Marriages: A Silent Revolution?” Economic and Political Weekly (27 October 2012): 100--108.

... Caste Aside: A Philosophical Study of Identity and Resistance of Punjabi Dalits (New Delhi: Routledge, forthcoming).

Fanon, Frantz. Black Skin White Masks, tr. Charles Lam Markmann (Peau noire, masques blancs, 1952; tr. 1967; London: Pluto, 2008).

Ghuman, Paul. British Untouchables: A Study of Dalit Identity and Education (Farnham: Ashgate, 2011).

Guru, Gopal, ed. Humiliation: Claims and Context (New Delhi: Oxford UP, 2009).

Hardtmann, Eva--Maria. The Dalit Movement in India: Local Practices, Global Connections (New Delhi: Oxford UP, 2009).

Juergensmeyer, Mark, Religion as Social Vision: the Movement against Untouchability in $20^{\text {th }}$ Century Punjab, (Berkeley: U of California P, 1982).

Metcalf, Hilary, \& Heather Rolfe. Caste Discrimination and Harassment in Great Britain (Report published by the National Institute of Economic and Social Research, December, 2010).

Nandy, Ashis. "Humiliation: Politics and the Cultural Psychology of the Limits of Human Degradation," in Humiliation: Claims and Context, ed. Gopal Guru (New Delhi: Oxford UP, 2009): 41--57.

Nesbitt, Eleanor. "Religion and Identity: The Valmiki Community in Coventry," New Community 16.2 (January 1990): $261--74$.

.... "Research Report: Studying the Religious Socialization of Sikh and 'Mixed-Faith' Youth in Britain: Contexts and Issues," Journal of Religion in Europe 2 (2009): 37-57.

Office of National Statistics, "Religion in England and Wales 2011" (11 December 2012), http://www.ons.gov.uk/ons/dcp171776_290510.pdf (accessed on 11 December 2012).

Ram, Ronki. "Beyond Conversion and Sanskritisation: Articulating an Alternative Dalit Agenda in East Punjab," Modern South Asian Studies 46.3 (May 2012): 639--702. doi:10.1017/S0026749X11000254.

Sato, Kiyotaka. "Divisions among Sikh Communities in Britain and the Role of Caste System: A Case Study of Four Gurdwaras in Multi-Ethnic Leicester," Journal of Punjab Studies 19.1 (2012): 1--26.

\footnotetext{
${ }^{29}$ Fanon, Black Skin, White Masks, 181.
} 